\title{
Differences between Aureobasidium Pullulans CGMCC No.3337 and Aureobasidium Pullulans TKPM10017 on Synthesis of Poly ( $\beta$-L-malic-acid) Metabolism
}

\author{
Hai-Song YIN ${ }^{1,2,3}$, Yan-Hui BIAN ${ }^{3}$, Wei-Hua TANG ${ }^{1,2}$, Xu-Jia FAN ${ }^{3}$, \\ Zheng LI ${ }^{5}$, Chang-Sheng QIAO ${ }^{3,4, a, ~ *}$
}

${ }^{1}$ School of Bioengineering, Tianjin Modern Vocational Technology College, Tianjin, 300350, China

${ }^{2}$ Tianjin Light Industrial chemical Rresearch institute of Co., LTD., Tianjin, 300350, China

${ }^{3}$ Key Laboratory of Industrial Fermentation Microbiology, Ministry of Education, Tianjin University of Science and Technology, Tianjin economic and technological development zone 13th avenue 29, Tianjin 300457, China

${ }^{4}$ Tianjin Peiyang Biotrans Co, Ltd, Tianjin 300457, China

${ }^{5}$ School of Textiles, Tianjin Polytechnic University, Tianjin 300387, China

aemail: qiaochangsheng@tust.edu.cn

*Corresponding author: Tel: +86-22-60601606, Fax: +86-22-60602298.

Keywords: Poly ( $\beta$-L-malic-acid) (PMLA), Aureobasidium pullulans, Protein spectrum experiment, Intracellular enzyme activity.

\begin{abstract}
Poly ( $\beta$-L-malic-acid) (PMLA) is a sort of polyester and absolute biodegradable material. PMLA is a new type of nontoxic macromolecule material and with favorable biodegradation and biocompatibility. PMLA has extensive applications in the areas of pharmacy and medical industry. Application foreground of PMLA is very extensive. Poly malic acid has widely attracted the attention of people, but the studies of poly malic acid - Aureobasidium pullulans (A.pullulans) and the metabolic mechanism of A.pullulans is rarely reported, the researchers abroad studied A.pullulans is earlier than domestic researchers. The Key Laboratory of Industrial Microbiology, Ministry of Education, Tianjin University of Science and Technology preserve two strains which have different production--Aureobasidium pullulans CGMCC No.3337 and Aureobasidium pullulans TKPM10017. A.pullulans CGMCC No.3337 was selected from A.pullulans TKPM10017 by UV and He-Ne laser. There were significant differences in production of PMLA. In order to study the significant differences, we carried out the protein spectrum experiment the extraction of genome of A.pullulans TKPM10017 and A.pullulans CGMCC No.3337 and the Polymerase Chain Reaction of ATP synthase alpha subunit and ATP synthase beta subunit and gene sequence analysis. From the metabolic pathway perspective analyze on the causes of such differences.
\end{abstract}

\section{Introduction}

Poly ( $\beta$-L-malic-acid) (PMLA) is a functional aliphatic polyester which is composed of malic acid repeating units [1]. Having pendant carboxylic groups allows the 
introduction of functional groups and molecules, including drugs via chemical modification. These advantages make it important to investigate high purity, high-yield production for this polymer. PMLA is a new type of nontoxic macromolecular material with favorable biodegradation and biocompatibility $[2,3]$, which has gained great industrial interest for its potential applications in medicine[4] and other industries. For example, it was reported that a PMLA-based drug delivery system and biodegradable nano particles could be used for tumor targeting [5]. Therefore PMLA can be used as prodrug or for drug delivery system, which has attracted a great deal of interest in industries $[6,7]$.

PMLA can be obtained by the method of chemical synthesis or microbial fermentation. Recently, biosynthesis has been extensively investigated. Schimada, K firstly reported biosynthetic PMLA by Penicillium cyclopium. Since then Physarum polycephalum, Aureobasidium sp., Aureobasidium pullulans [8, 9], and several other myxomycetes and mitosporic fungi [10] have been reported to produce the polymer successively. According to the reports that Aureobasidium sp. is the bestest strain to product PMLA, yield changes following the strains of the different properties.However, under natural conditions, the productivity of PMLA is still in a low level, and few domestic researches on the production of PMLA by Aureobasidium pullulans have been carried out [11, 12].

Aureobasidium pullulans CGMCC No.3337 is the high-yielding strain, and its production of PMLA is much higher than Aureobasidium pullulans TKPM10017 (the original strain of the high-yielding strain). Such a giant change attracts our attention to investigate. We have known that there are obvious differences in production of PMLA, while we can't get across the reason. We try to make the reason clear through the metabolic flux analysis and metabonomics analysis.

\section{Materials and Methods}

\section{Strain and Medium}

Aureobasidium pullulans CGMCC No.3337 was isolated by the Key Laboratory of Industrial Microbiology, Ministry of Education, Tianjin University of Science and Technology. A.pullulans CGMCC No.3337 was selected from A.pullulans TKPM10017 by UV and He-Ne laser. The cells were grown on LB mediums for 3 days at $25{ }^{\circ} \mathrm{C}$ and stored at $4{ }^{\circ} \mathrm{C}$.

The medium for inoculum preparation (seed medium) contained the following components $(\mathrm{g} / \mathrm{L})$ : glucose 140 , yeast extract $3,\left(\mathrm{NH}_{4}\right)_{2} \mathrm{SO}_{4} 1$, succinic acid 2 , $\mathrm{K}_{2} \mathrm{CO}_{3} 0.4, \mathrm{KH}_{2} \mathrm{PO}_{4} \quad 0.1, \mathrm{CaCO}_{3} 20, \mathrm{ZnSO}_{4} \cdot 7 \mathrm{H}_{2} \mathrm{O} 5 \times 10^{-3}, \mathrm{MgSO}_{4} \cdot 7 \mathrm{H}_{2} \mathrm{O} 0.1$, corn steep liquor $0.1 \%(\mathrm{v} / \mathrm{v})$.

The fermentation medium for flask culture was consisted of the following components (g/L): glucose 180 , peptone $35, \mathrm{KCl} 0.5, \mathrm{KH}_{2} \mathrm{PO}_{4} 0.1, \mathrm{NaNO}_{3} 2, \mathrm{MnSO}_{4}$ $0.05, \mathrm{MgSO}_{4} \cdot 7 \mathrm{H}_{2} \mathrm{O} 0.3, \mathrm{CaCO}_{3} 20$. The initial $\mathrm{pH}$ of the medium was adjusted by using $5 \mathrm{M} \mathrm{NaOH}$ and $6 \mathrm{M} \mathrm{HCl}$ to 7.0.

\section{Cultivation Methods}

Shake-flask Culture. The cells growing on newly prepared were transferred to 500 
$\mathrm{ml}$ shake flask containing $50 \mathrm{ml}$ seed medium and incubated at $25^{\circ} \mathrm{C}$ and $200 \mathrm{rpm}$ for inoculums preparation. The cells used for experiment was carried out by $500 \mathrm{ml}$ shake flask containing $50 \mathrm{ml}$ fermentation medium and incubated at $25^{\circ} \mathrm{C}$ and $200 \mathrm{rpm}$.

Fermentation Cylinder Culture. The seed prepared for the bioreactor was cultured in the Erlenmeyer flask each time. When its absorbance measured at $600 \mathrm{~nm}$ using a ultraviolet spectrophotometer (UV-1800PC, China), was at 0.6-0.7, transferred it to a $10.0 \mathrm{~L}$ bioreactor (Shanghai, China) containing $7 \mathrm{~L}$ fermentation culture medium. Fermentation conditions: the dissolved oxygen $30 \%$, ventilation rate 1:1.2, initial stirring speed 300-600 rpm, $\mathrm{pH} 7.0$, fermentation temperature $25^{\circ} \mathrm{C}$, inoculum size $10 \%$,fermentation time 7 days.

\section{OD and Biomass}

OD. Cell growth was determined by measuring the absorbance at $600 \mathrm{~nm}$ using a ultraviolet spectrophotometer (UV-1800PC, China).

Biomass Concentration. Two milliliter of broth mixed $3 \mathrm{M} \mathrm{HCl}$ (aim to wipe off calcium carbonate) was centrifuged at $2000 \mathrm{xg}$ at $4^{\circ} \mathrm{C}$ for $20 \mathrm{~min}$ (Microfuge 18, Beckman Coulter Co., Fullerton, CA). Then, the precipitate were washed twice with distilled water and centrifuged again to remove impurities. After the precipitate were dried at $80^{\circ} \mathrm{C}$ overnight $(>8 \mathrm{~h}$ ), dry weight amortized computation with fermentation broth was determined as biomass.

\section{Quantitative Analysis of PMLA}

The concentration of PMLA was determined by a reversed phase high performance liquid chromatography method on a column of prevail $\mathrm{C} 18(4.6 \mathrm{~mm} \times 250 \mathrm{~mm}, 4 \mu \mathrm{m})$ with a mobile phase containing acetonitrile and $0.025 \mathrm{M} \mathrm{KH}_{2} \mathrm{PO}_{4}$ buffer $(\mathrm{pH} 2.5)$ $(5: 95, \mathrm{v}: \mathrm{v})$, the flow rate of mobile phase was $1.0 \mathrm{~mL} / \mathrm{min}$, the detection wavelength was $210 \mathrm{~nm}$ and the column temperature was $25^{\circ} \mathrm{C}$. Before sampling, the fermentation broth was centrifuged and hydrolysed. L-malic acid were completely separated and determined in 4 minutes.

\section{Protein Spectrum Experiment}

The experimental method: protease digestion, LC-MS/MS detection. HPLC conditions: mobile phase: liquor $\mathrm{A}_{2} \mathrm{O}$ (mass spectrometry), liquor $\mathrm{B}$ acetonitrile (mass spectrometry); Flow rate: $200 \mathrm{ul} / \mathrm{min}$ (after shunt $2 \mathrm{ul} / \mathrm{min}$ ); the elution gradient: $120 \mathrm{~min}$ (5\% B to $35 \% \mathrm{~B}$ in $40 \mathrm{~min}$, to $95 \%$ in $20 \mathrm{~min}$, balance for $20 \mathrm{~min}$ ); Sample: sample automatically; Sample quantity: $20 \mathrm{ul}$.

\section{The Detection of Intracellular Enzyme Activity}

We detect the intracellular enzymes: Pyruvate carboxylation kinase enol phosphate, Pyruvate carboxylase, Malate synthetase Malic dehydrogenase, Fumarate hydratase $[13,14]$. 


\section{Results}

The Production of PMLA from A.pullulans CGMCC No.3337 and A.pullulans TKPM10017

As is shown in the table 1 , the maximum PMLA concentration( $\mathrm{P}$ max), the optimal specific product yield(YP/X) and the optimal product yield(YP/S) of A.pullulans CGMCC No.3337 are much higher than A.pullulans TKPM10017, the specific growth $\operatorname{rate}(\mu)$, the optimal cell production $\operatorname{rate}(\mathrm{QX})$, the optimal production formation rate $(\mathrm{QP})$, the maximum cell density $(\mathrm{X} \max )$, the optimal cell yield(YX/S) of A.pullulans CGMCC No.3337 are respectively a little bit higher than A.pullulans TKPM10017. The results showed that the growth conditions of A.pullulans CGMCC No.3337 are better than A.pullulans TKPM10017. Through mutagenesis, the maximum PMLA production of A.pullulans CGMCC No.3337 could reach $78.85 \pm 0.329 \mathrm{~g} / \mathrm{L}$, which was increased by $85.14 \%$ compared with A.pullulans TKPM10017.As is shown in Fig. 1.

Table1 The growth condition of A.pullulans and yield in the process of fermentation

\begin{tabular}{lcccccccc}
\hline & $\mu\left(\mathrm{h}^{-1}\right)$ & $\mathrm{Q}_{\mathrm{X}}(\mathrm{g} / \mathrm{Lh})$ & $\mathrm{Q}_{\mathrm{P}}(\mathrm{g} / \mathrm{Lh})$ & $\mathrm{X}_{\max }(\mathrm{g} / \mathrm{L})$ & $\mathrm{P}_{\max }(\mathrm{g} / \mathrm{L})$ & $\mathrm{Y}_{\mathrm{X} / \mathrm{S}}(\mathrm{g} / \mathrm{g}) \mathrm{Y}_{\mathrm{P} / \mathrm{S}}(\mathrm{g} / \mathrm{g})$ & $\mathrm{Y}_{\mathrm{P} / \mathrm{X}}(\mathrm{g} / \mathrm{g})$ \\
\hline $\begin{array}{l}\text { A.pullulans } \\
\text { TKPM10017 }\end{array}$ & 0.1387 & 0.7867 & 0.6825 & 43.1 & 42.59 & 0.2395 & 0.2199 & 0.9186 \\
$\begin{array}{l}\text { A.pullulans } \\
\text { CGMCC }\end{array}$ & 0.1579 & 0.9142 & 0.9575 & 49.23 & 78.85 & 0.2735 & 0.4583 & 1.6758 \\
No.3337 & & & & & & & & \\
\end{tabular}

$\mu$-the specific growth rate; $\mathrm{Q}_{\mathrm{X}}$-the optimal cell production rate; $\mathrm{Q}_{\mathrm{P}^{-}}$the optimal production formation rate; $\mathrm{X}_{\max }$-the maximum cell density; $\mathrm{P}_{\max }$-the maximum PMLA concentration; $\mathrm{Y}_{\mathrm{X} / \mathrm{S}}$-the optimal cell yield; $\mathrm{Y}_{\mathrm{P} / \mathrm{S}^{-}}$the optimal product yield; $\mathrm{Y}_{\mathrm{P} / \mathrm{X}^{-}}$the optimal specific product yield.
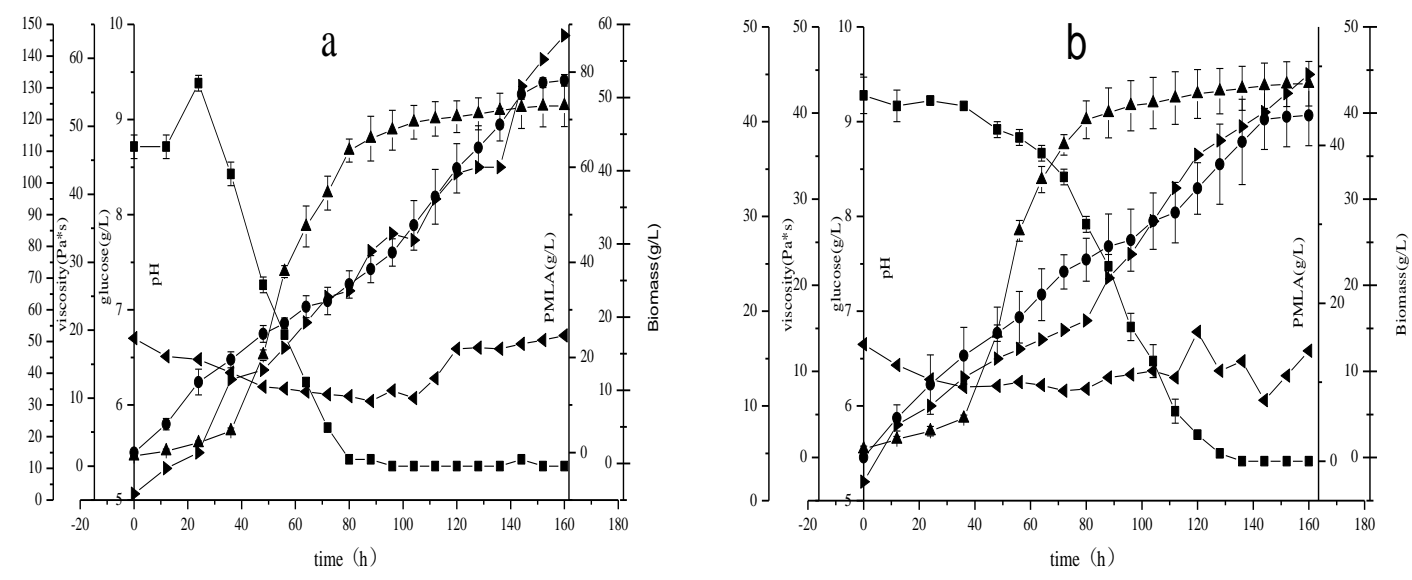

Figure 1. The differences of the strain Aureobasidium pullulans CGMCC No.3337 and the strain Aureobasidium pullulans TKPM10017 on the synthesis of poly( $\beta$-L-malic-acid) metabolism. Aureobasidium pullulans CGMCC No.3337(a), Aureobasidium pullulans TKPM10017(b), $\operatorname{viscosity}(\bullet)$, the residual glucose $(\boldsymbol{\bullet}), \mathrm{pH}(\boldsymbol{\bullet})$, $\operatorname{biomass}(\boldsymbol{\Delta}), \operatorname{PMLA}(\bullet)$. 


\section{Protein Spectrum Analysis Total Protein of Aureobasidium Pullulans}

Protein spectrum according to the results: 51 protein were detected in A.pullulans TKPM10017; while, 55 protein were detected in A.pullulans CGMCC No.3337. Among the proteins, there are 8 protein showed increased over $40 \%$ in A.pullulans CGMCC No.3337 than in A.pullulans TKPM10017; while there are 12 protein showed decreased over 40\% in A.pullulans CGMCC No.3337 than in A.pullulans TKPM10017.

The protein spectrum results show that many proteins and enzymes, such as ATP synthase subunit beta, UDP-glucose pyrophosphorylase, glucose-6-phosphate isomerase, pyruvate carboxylation kinase enol phosphate, malic dehydrogenase , 6-phosphofructokinase subunit beta, fumarate hydratase, pyruvic carboxylase, Fatty acid synthase subunit alpha, Protein kinase C-like 1, malate synthase, the proteins and enzymes acting the key enzymes respectively in Tricarboxylic acid cycle, Pyruvate carboxylation and Glyoxylate cycle play an important role. The results are shown in the following table 2 .

Table 2. (a) Protein spectrum analysis total protein of A.pullulans TKPM10017

\begin{tabular}{|c|c|c|c|c|c|c|}
\hline Accession & Coverage & PSM & \# AAs & $\begin{array}{c}\mathrm{MW} \\
{[\mathrm{kDa}]}\end{array}$ & Score & Description \\
\hline P00830 & 18.79 & 28 & 511 & 54.8 & 59.3 & $\begin{array}{l}\text { ATP synthase subunit beta, mitochondrial } \\
\text { OS=Saccharomyces cerevisiae (strain ATCC } \\
204508 \text { / S288c) }\end{array}$ \\
\hline P08417 & 8.03 & 16 & 488 & 53.2 & 83.2 & $\begin{array}{l}\text { fumarase FUM1 [Saccharomyces cerevisiae } \\
\text { S288c] }\end{array}$ \\
\hline P07251 & 8.81 & 8 & 545 & 58.6 & 63.9 & UDP-glucose pyrophosphorylase \\
\hline P10490 & 6.29 & 17 & 966 & 110.7 & 93.1 & $\begin{array}{l}\text { RecName: Full=Phosphoenolpyruvate } \\
\text { carboxylase 1; Short=PEPC 1; } \\
\text { Short=PEPCase } 1\end{array}$ \\
\hline P11154 & 4.07 & 9 & 1,178 & 130.1 & 91.6 & $\begin{array}{l}\text { Pyruvate carboxylase } 1 \text { Saccharomyces } \\
\text { cerevisiae (strain ATCC } 204508 \text { / S288c) } \\
\text { (Baker's yeast) }\end{array}$ \\
\hline P12709 & 5.78 & 20 & 554 & 61.3 & 75.4 & $\begin{array}{l}\text { Glucose-6-phosphate isomerase } \\
\text { OS=Saccharomyces cerevisiae (strain ATCC } \\
204508 \text { / S288c) }\end{array}$ \\
\hline P13697 & 6.13 & 5 & 572 & 64.0 & 89.3 & $\begin{array}{l}\text { RecName: Full=NADP-dependent malic } \\
\text { enzyme; Short=NADP-ME; AltName: } \\
\text { Full=Malic enzyme } 1\end{array}$ \\
\hline P16862 & 2.09 & 4 & 959 & 104.6 & 76.0 & $\begin{array}{l}\text { 6-phosphofructokinase subunit beta } \\
\text { OS=Saccharomyces cerevisiae (strain ATCC } \\
204508 \text { / S288c) }\end{array}$ \\
\hline P30952 & 4.23 & 10 & 554 & 62.8 & 86.5 & $\begin{array}{l}\text { malate synthase MLS1 [Saccharomyces } \\
\text { cerevisiae S288c] }\end{array}$ \\
\hline
\end{tabular}

\# PSMs-Number of peptides; \# AAs-Number of amino acids; MW [kDa]-molecular weight 
Table 2. (b) Protein spectrum analysis total protein of A.pullulans CGMCC No.3337

\begin{tabular}{|c|c|c|c|c|c|c|}
\hline Accession & Coverage & \# PSMs & \#AAs & $\begin{array}{l}\mathrm{MW} \\
{[\mathrm{kDa}]}\end{array}$ & Score & Description \\
\hline P00830 & 19.77 & 51 & 511 & 54.8 & 83.6 & $\begin{array}{l}\text { ATP synthase subunit beta, mitochondrial } \\
\text { OS=Saccharomyces cerevisiae (strain ATCC } \\
204508 \text { / S288c) }\end{array}$ \\
\hline P08417 & 8.31 & 29 & 488 & 53.2 & 83.2 & $\begin{array}{l}\text { fumarase FUM1 [Saccharomyces cerevisiae } \\
\text { S288c] }\end{array}$ \\
\hline P10490 & 8.52 & 33 & 966 & 110.7 & 93.1 & $\begin{array}{l}\text { RecName:Full=Phosphoenolpyruvate } \\
\text { carboxylase } 1 \text {; Short=PEPC } 1 \text {; Short=PEPCase } \\
1\end{array}$ \\
\hline P11154 & 6.79 & 17 & 1,178 & 130.1 & 91.6 & $\begin{array}{l}\text { Pyruvate carboxylase } 1 \text { Saccharomyces } \\
\text { cerevisiae (strain ATCC 204508 / S288c) } \\
\text { (Baker's yeast) }\end{array}$ \\
\hline P13697 & 8.12 & 8 & 572 & 64.0 & 89.3 & $\begin{array}{l}\text { RecName: } \quad \text { Full=NADP-dependent malic } \\
\text { enzyme; Short=NADP-ME; AltName } \\
\text { Full=Malic enzyme } 1\end{array}$ \\
\hline P19097 & 2.17 & 5 & 1887 & 206.8 & 30.8 & $\begin{array}{l}\text { Fatty acid synthase subunit alpha } \\
\text { OS=Saccharomyces cerevisiae (strain ATCC } \\
204508 \text { / S288c) }\end{array}$ \\
\hline P24583 & 3.65 & 10 & 1151 & 131.4 & 27.3 & $\begin{array}{l}\text { Protein kinase C-like } 1 \text { OS=Saccharomyces } \\
\text { cerevisiae (strain ATCC } 204508 \text { / S288c) }\end{array}$ \\
\hline P30952 & 5.83 & 11 & 554 & 62.8 & 86.5 & $\begin{array}{l}\text { malate synthase MLS1 [Saccharomyces } \\
\text { cerevisiae S288c] }\end{array}$ \\
\hline
\end{tabular}

\# PSMs-Number of peptides; \# AAs-Number of amino acids; MW [kDa]-molecular weight

\section{The Detection of Intracellular Enzyme Activity}

According to the formula $\mathrm{U} / \mathrm{ml}=\frac{\frac{\Delta \mathrm{A}}{\min } * \text { the test volume*dilution ratio }}{\text { absorption coefficient*optical path*enzyme volume }}$ (the test volume: $100 \mu \mathrm{L}$, dilution ratio: 1 , absorption coefficient: $\varepsilon_{340}=6.22 \times 10^{3}$ $\mathrm{L} /(\mathrm{mol} \cdot \mathrm{cm})$, optical path:3mm, enzyme volume: $5 \mu \mathrm{L})$ count the intracellular enzyme enzyme activity.The results reflected in Fig. 2.

Comprehensive analysis the above figures and the metabolic pathways of Aureobasidium pullulans, Pyruvate carboxylation kinase enol phosphate, Malate synthase, Malic dehydrogenase and Fumarate hydratase in the Tricarboxylic cycle, Pyruvic carboxylase in the Pyruvate carboxylation, Malate synthase, Malic dehydrogenase in the Glyoxylate cycle, the activity of the five kinds of intracellular enzyme in A.pullulans CGMCC No.3337 were significantly higher than A.pullulans TKPM10017. The test result of the experimental detection of intracellular enzyme activity confirms the results of the protein mass spectrometry experiments that the enzymes play an important role in the metabolic pathways. Therefore, these data can make a conclusion that the enzymes make a great effect to generate PMLA. 
Synthesizing the results of the protein mass spectrometry experiments analysis total protein of Aureobasidium pullulans and the experimental detection of intracellular enzyme activity: the results of the protein mass spectrometry experiments analysis total protein of Aureobasidium pullulans indicates that the number of proteins and enzymes in A.pullulans CGMCC No.3337 are obviously more than A.pullulans TKPM10017; the results of the experimental detection of intracellular enzyme activity illustrates that the activity of the five kinds of intracellular enzyme in A.pullulans CGMCC No.3337 were significantly higher than A.pullulans TKPM10017. The results have shown that the increase of the number of enzymes enhance the enzyme activity, lead to the increase of metabolic flux, increase the production of PMLA.
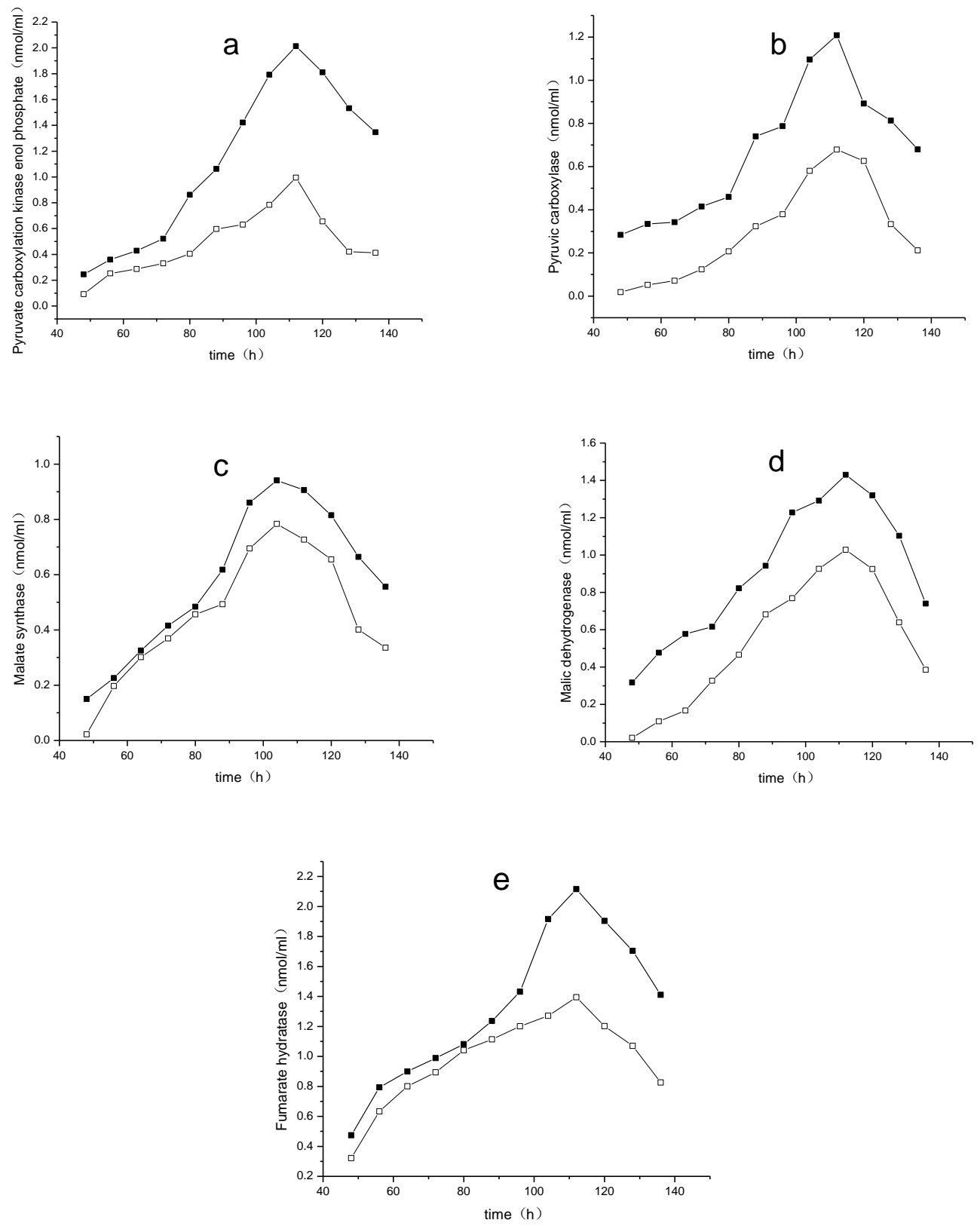

Figure 2. Pyruvate carboxylation kinase enol phosphate (a), Pyruvic carboxylase(b), Malate synthase(c), Malic dehydrogenase(d),Fumarate hydratase(e), enzyme activity change over time. A.pullulans TKPM10017 (ם), A.pullulans CGMCC No.3337(匹). 


\section{Discussion}

The results of the protein spectrum analysis total protein of Aureobasidium pullulans indicates that the number of proteins and enzymes in A.pullulans CGMCC No.3337 are obviously more than those in A.pullulans TKPM10017; the results of the enzyme activity detection experiments illustrates that the activity of the five kinds of intracellular enzyme in A.pullulans CGMCC No.3337 is significantly higher than in A.pullulans TKPM10017.The results have shown that the increase in the number of enzymes enhances the enzyme activity, leading to the increase of metabolic flux, PMLA production.

The study has shown that there are significant differences of PMLA production from A.pullulans CGMCC No.3337 and A.pullulans TKPM10017. Through carrying on the protein mass spectrometry experiments analysis total protein of Aureobasidium pullulans and the experimental detection of intracellular enzyme activity, we have found out and verified the reason why the production of PMLA increased significantly from A.pullulans CGMCC No.3337. This new and improved theory of PMLA production process methodology will conceivably provide significant contribution and insight, and possibly also to other relevant fermentation processes for the improvement of product yield and productivity at the industrial scale.

\section{Acknowledgement}

This work was financially supported by the Program of Tianjin University of Science and Technology, and the Program of the company of Tianjin Peiyang Biotrans, and the Program of Tianjin science and technology plan under No.14ZCZDTG00025. The authors would like to thank these organizations for their generous financial support.

\section{References}

[1] Holler, M.,Cardinali, F.,Mamlouk, H., Nierengarten, J., et al., 2006. Synthesis of Fullerohelicates and Fine Tuning of the Photoinduced Processes by Changing the Number of Addends on the Fullerene Subunits. ChemInform., 62(9), 2060-2073.

[2] Fujita, M.,Khazenzon, NM.,Ljubimov, AV., Seop Lee, B., et al., 2006. Inhibition of laminin-8 in vivo using a novel poly(malic acid)-based carrier reduces glioma angiogenesis. Angiogenesis., 9(4), 183-191.

[3] Gödde, C., Liebergesell, M., Steinbüchel, A., 1999. Isolation of poly(beta-L-malic acid)-degrading bacteria and purification and characterization of the PMA hydrolase from Comamonas acidovorans strain 7789. FEMS Microbiology letters., 173, 365-372.

[4] Osanai, S., Nakamura, K., 2000. Effects of complexation between liposome and poly(malic acid) on aggregation and leakage behaviour. Biomaterials., 21, 867-876.

[5] Fujita, M., Lee, B., Khazenzon, N., Penichet, ML., et al., 2007. Brain tumor tandem targeting using a combination of monoclonal antibodies attached to biopoly ( $\beta$-L-malic acid). Journal of Controlled Release., 122, 356-363. 
[6] Ljubimova, J., Fujita, M., Ljubimov, A., Torchilin, VP., et al., 2008. Poly (malic acid) nanoconjugates containing various antibodies and oligonucleotides for multitargeting drug delivery. Nanomedicine., 3, 247-265.

[7] Ding, H., Portilla-Arias, J., Patil, R., Black, KL., et al., 2011.The optimization of polymalic acid peptide copolymers for endosomolytic drug delivery. Biomaterials., 32, 5269-5278.

[8] Ding, H., Inoue, S., Ljubimov, AV., patil, R., et al., 2010. Inhibition of brain tumor growth by intravenous poly ( $\beta$-L-malic acid) nanobioconjugate with pH-dependent drug release. Proceedings of the National Academy of Sciences., 107, 18143-18148.

[9] Shuangjiang, L., Steinbüchel, A., 1996. Investigation of poly( $\beta$-malic acid) production by strains of Aureobasidium pullulans. Appl Microbiol Biotechnol .,46, 273- 278.

[10] Shuangjiang, L., Steinbüchel, A., 1997. Production of poly(malic acid) from different carbon sources and its regulation in Aureobasidium pullulans. Biotechnol Lett., 19, 11-14.

[11] Rathberger, K., Reisner, H., 1999. Comparative synthesis and hydrolytic degradati on of poly (L- malate) by myxomycetes and fungi. Mycol Res., 103, 513520.

[12] Weifeng, C., Jianquan, L., Juan, Z., Changsheng, Q., et al., 2012. Intensification of $\beta$-poly(L-malicacid) production by Aureobasidium pullulans ipe-1 in the late exponential growth phase. Journal of Industrial Microbiology \& Biotechnology., 39(7), 1073-1080.

[13] Murphey W H,Kitto G B(1969)Malate dehydrogenase from Escherichia coli [J],Methods in Enzymology,(13):145-147.

[14] Shi Qiaoqin,Wu Songgang,Zheng Teng, et al(2003) The study is about synthesis of fumarase in L-malic acid producing bacteria mutants F-871[J].Mycosystema, (2):283-288. 